\title{
Pengaruh Kualitas Pelayanan dan Harga Tambahan Layanan terhadap Kepuasan Konsumen Pengguna Jasa Kapal Penyebrangan PT. Trisakti Lautan Mas di Bakauheni
}

\author{
Gugup Tugi Prihatma \\ Adi Sulaiman \\ prihatma16@yahoo.co.id \\ Universtas Serang Raya
}

\begin{abstract}
ABSTRAK
Kepuasan pelanggan akan terbentuk jika dapat memenuhi harapan-harapan dasar konsumen. Banyak faktor yang mempengaruhi kepuasan konsumen diantaranya kualitas pelayanan dan harga.Permasalahan dalam penelitan ini adalah (1) Bagaimana pengaruh kualitas pelayanan terhadap kepuasan konsumen, (2) Bagaimana pengaruh harga tambahan layanan terhadap kepuasan konsumen, (3) Bagaimana pengaruh kualitas pelayanan dan harga tambahan layanan secara simultan terhadap kepuasan konsumen.Hasil penelitian diperoleh persamaan regresi linier berganda $\mathrm{Y}=13,122+0,159 \mathrm{X}_{1}+0,145 \mathrm{X}_{2}$. Kualitas pelayanan tidak berpengaruh positif dan tidak signifikan terhadap kepuasan konsumen dengan nilat $\mathrm{t}=1,459$, harga tambahan layanan tidak terdapat pengaruh positif dan tidak signifikan terhadap kepuasan konsumen dengan nilai $t=1,441$, kualitas pelayanan dan harga tambahan layanan secara bersama-sama tidak terdapat pengaruh signifikan terhadap kepuasan konsumen dengan nilai $F=3,012$. Secara keseluruhan kualitas pelayanan dan harga tambahan layanan mempengaruhi kepuasan konsumen sebesar 0,048 atau 4,8\%, Sedangkan sisanya 95,2\% dipengaruhi oleh faktor lain yang tidak diteliti. Berdasarkan penelitian ini dapat disimpulkan bahwa : 1) Tidak terdapat pengaruh postif dan tidak signifikan antara kualitas pelayanan terhadap kepuasan konsumen 2) Tidak terdapat pengaruh postif dan tidak signifikan antara harga tambahan layanan terhadap kepuasan konsumen 3) Tidakterdapat pengaruh positif dan signifikan antara kualitas pelayananharga tambahan layanan secara simultan terhadap kepuasan konsumen.

Kata kunci: Kualitas Pelayanan, Harga, Kepuasan Konsumen
\end{abstract}

\begin{abstract}
Customer satisfaction will be formed if it can meet the expectations of the consumer base. Many factors that affect customer satisfaction including the quality of service and price. The problem in this research is (1) How does the quality of service to customer satisfaction, (2) How does the price of the additional services to customer satisfaction, (3) How does the quality of service and price of the additional services simultaneously on customer satisfaction. The results obtained by multiple linear regression equation $\mathrm{Y}=13,122+0.159 \mathrm{X} 1+$ $0.145 \mathrm{X} 2$. Quality of service is not positive and not significant to customer satisfaction with the grades were $t=1.459$, the price of the additional services are not there is positive and no significant effect on customer satisfaction with the value $t=1.441$, quality of service and price of the additional services together no significant effect on consumer satisfaction with the value of $F=3.012$. Overall
\end{abstract}


quality of service and price of the additional services affect customer satisfaction by 0.048 or $4.8 \%$, while the remaining $95.2 \%$ is influenced by other factors not examined. Based on this research can be concluded that: 1) there are significant positive and significant correlation between quality of service to customer satisfaction 2) There is no influence of positive and significant correlation between the price of the additional services to customer satisfaction 3 ) there is positive and significant correlation between quality of service price additional services simultaneously on customer satisfaction.

Keyword: Service Quality, Price, Customer Satisfaction

\section{PENDAHULUAN}

\section{Latar Belakang Masalah}

Pelabuhan Bakauheni -Merak dipisahkan oleh Selat Sunda yang mempunyai jarak 16 mil $(25.75 \mathrm{~km})$ dapat ditempuh dengan 2 jam hingga 4 jamkarena dermaga yang tersedia belum optimal berjalan serta tergantung cuaca. Hal ini dapatmenghambat perpindahan barang atau jasa yang menyebabkanmeningkatnya waktu perpindahan dari tempat asal diperlukan pelayanan yang baik untuk menjaga tingkat kejenuhan masyarakat pengguna jasa kapal penyeberangan.

PT. Trisakti Lautan Mas sebagai penyelenggara penyeberangan baik barang maupun penumpang dari satu pulau ke pulau lainnya sangatlah berperan penting dalam penyelenggaraan transportasi publik.Hasil observasi langsung pada perusahaan PT Trisakti Lautan Masmenemukan banyak perbedaan mengenai pelayanan dan biayatambahan layanan yang sudah ditentukan dengan setiap kapal tersebutuntuk mendapatkan fasilitas seperti berikut :

Tabel 1

Data Fasilitas Pelayanan dan Harga Tambahan Layanan pada PT. Trisakti Lautan Mas

\begin{tabular}{|c|c|c|c|c|}
\hline \multirow{2}{*}{$\begin{array}{l}\mathbf{N} \\
\mathbf{O}\end{array}$} & \multirow{2}{*}{ NAMA KAPAL } & \multicolumn{2}{|c|}{ KUALITAS PELAYANAN } & \multirow{2}{*}{$\begin{array}{c}\text { HARGA } \\
\text { TAMBAHAN } \\
\text { LAYANAN } \\
\text { HARGA } \\
\text { TAMBAHAN }\end{array}$} \\
\hline & & FASILITAS & KETERANGAN & \\
\hline 1 & $\begin{array}{c}\text { Trimas Kanaya } \\
\text { (Surabaya) } \\
\text { No.0217431117 }\end{array}$ & $\begin{array}{l}\text { Ruang Eksekutif } \\
\text { Ruang ekonomi } \\
\text { Ruang lesehan } \\
\text { Ruang khusus } \\
\text { supir } \\
\text { Ruang Ibadah } \\
\text { /Mushola } \\
\text { Bantal } \\
\text { Parkir } \\
\text { Kafetaria } \\
\text { Charge } \\
\text { Handphone } \\
\text { Pijat/refleksi } \\
\text { Alat } \\
\text { Keselamatan } \\
\end{array}$ & $\begin{array}{l}\text { Luas } 120 \mathrm{M}^{2} \\
\text { Luas } 450 \mathrm{M}^{2} \\
\text { Luas } 300 \mathrm{M}^{2} \\
\text { Luas } 75 \mathrm{M}^{2} \\
\text { Luas } 12 \mathrm{M}^{2} \\
\text { Ruangan kelas } \\
\text { Luas } 1.500 \mathrm{M}^{2} \\
\text { Restorasi, kantin } \\
\text { Di kantin } \\
\text { Petugas pijat } \\
\text { Jaket pelampung, } \\
\text { alat pemadam } \\
\text { kebakaran, petunjuk } \\
\text { jalur evakuasi, }\end{array}$ & $\begin{array}{c}\text { Rp.10.000,- } \\
\text { Gratis } \\
\text { Rp.8.000,- } \\
\text { Gratis } \\
\text { Gratis } \\
\text { Rp.3.000,- } \\
\text { Gratis } \\
- \\
\text { Rp.5.000,- } \\
\text { Rp. 50.000,- } \\
-\end{array}$ \\
\hline
\end{tabular}




\begin{tabular}{|c|c|c|c|c|}
\hline & & $\begin{array}{l} \\
\text { fasilitas } \\
\text { Keamanan } \\
\text { Toilet } \\
\text { Petugas kapal : } \\
\text { Kapten } \\
\text { Nahkoda } \\
\text { ABK } \\
\text { Pramugari/a } \\
\text { Clening servce } \\
\text { Pegawai } \\
\text { Kafetaria } \\
\end{array}$ & $\begin{array}{l}\text { Skoci. } \\
\text { Petugas keamanan } \\
\text { Jumlah } 10 \\
\\
1 \\
1 \\
2 \\
18 \\
4 \\
10 \\
10\end{array}$ & $\begin{array}{c}\text { Gratis } \\
-\end{array}$ \\
\hline 2 & $\begin{array}{c}\text { Trimas Laila } \\
\text { (Surabaya) } \\
\text { No.3526177462 } \\
1\end{array}$ & $\begin{array}{l}\text { Ruang } \\
\text { Eksekutif } \\
\text { Ruang ekonomi } \\
\text { Ruang lesehan } \\
\text { Ruang khusus } \\
\text { sopir } \\
\text { Ruang Ibadah } \\
\text { /Mushola } \\
\text { Bantal } \\
\text { Parkir } \\
\text { Kafetaria } \\
\text { Charge } \\
\text { Handphone } \\
\text { Pijat/ refleksi } \\
\text { Alat } \\
\text { Keselamatan } \\
\end{array}$ & $\begin{array}{l}\text { Luas } 135 \mathrm{M}^{2} \\
\text { Luas } 450 \mathrm{M}^{2} \\
\text { Luas } 300 \mathrm{M}^{2} \\
\text { Luas } 75 \mathrm{M}^{2} \\
\text { Luas } 15 \mathrm{M}^{2} \\
\text { Ruang Kelas } \\
\text { Luas 1.650 M² } \\
\text { Restorasi, kantin } \\
\text { Dikantin } \\
\text { Khusus supir Truck } \\
\text { Jaket pelampung, } \\
\text { alat pemadam } \\
\text { kebakaran, petunjuk } \\
\text { jalur evakuasi, } \\
\text { Skoci. } \\
\text { Petugas keamanan } \\
\text { Jumlah } 10 \\
\qquad 1 \\
2 \\
4 \\
4 \\
12 \\
\end{array}$ & $\begin{array}{c}\text { Rp.10.000,- } \\
\text { Gratis } \\
\text { Rp.8.000,- } \\
\text { Gratis } \\
\text { Gratis } \\
\text { Rp.3.000,- } \\
\text { Gratis } \\
- \\
\text { Rp.5.000,- } \\
\text { Rp.50.000,- } \\
- \\
\\
\text { Gratis }\end{array}$ \\
\hline
\end{tabular}


Sebagai penyedia jasa masih terindikasi belum sesuai dengan adanya harga tambahan yang dikeluarkan konsumen untuk mendapatkan fasilitas dibandingkan dengan perusahaan pesaing yang memberikan fasilitas tanpa harga tambahan. Kapal masih kurangnya informasi yang memudahkan konsumen mendapatkan informasi tentang ruangan dan fasilitas yang disediakan, masih kurangnya fasilitas keamanan seperti kamera CCTV,kurangnya fasilitas hiburan yang mengakibatkan konsumen merasa jenuh selama pelayanan dan waktu selama pelayaran terkesan lama,dan toilet umum yang kurang bersih.

Tabel 2

Data pengguna jasa kapal pada PT.Trisakti Lautan Mas cabang Bakauheni Lampung

\begin{tabular}{|c|c|c|c|c|c|c|c|c|c|c|c|c|c|c|}
\hline $\begin{array}{c}\text { Bula } \\
\mathbf{n}\end{array}$ & $\begin{array}{c}\text { Tri } \\
\text { p }\end{array}$ & $\begin{array}{l}\text { Pnp } \\
\text { Dws } \\
\text { dan } \\
\text { Ank }\end{array}$ & $\begin{array}{l}\text { Spd.Dy } \\
\text { g Gol I }\end{array}$ & $\begin{array}{c}\text { Spd. } \\
\text { Mtr } \\
\text { Gol } \\
\text { II }\end{array}$ & $\begin{array}{c}\text { Bem } \\
\text { o Gol } \\
\text { III }\end{array}$ & $\begin{array}{c}\text { KK } \\
\text { Gol } \\
\text { IV } \\
\text { A }\end{array}$ & $\begin{array}{c}\text { TK } \\
\text { Gol } \\
\text { IV } \\
\text { B }\end{array}$ & $\begin{array}{c}\text { BS } \\
\text { Go } \\
\text { I V } \\
\text { A }\end{array}$ & $\begin{array}{c}\text { TS } \\
\text { Gol } \\
\text { V B }\end{array}$ & $\begin{array}{c}\text { BB } \\
\text { Go } \\
\text { I } \\
\text { VI } \\
\text { A }\end{array}$ & $\begin{array}{c}\text { TB } \\
\text { Gol } \\
\text { VI } \\
\text { B }\end{array}$ & $\begin{array}{l}\text { TR } \\
\text { Gol } \\
\text { VII }\end{array}$ & $\begin{array}{c}\text { Gol. } \\
\text { VII } \\
\text { I }\end{array}$ & $\begin{array}{l}\text { Gol } \\
\text {. IX }\end{array}$ \\
\hline Apr & 54 & 1342 & 0 & 363 & 0 & 682 & 162 & 11 & 541 & 97 & 757 & 312 & 53 & 5 \\
\hline Mei & 69 & 982 & 7 & 367 & 0 & $\begin{array}{c}105 \\
3 \\
\end{array}$ & 150 & 33 & 616 & 118 & 938 & 369 & 34 & 1 \\
\hline Jun & 75 & 1530 & 1 & 335 & 1 & 977 & 134 & 5 & 694 & 52 & $\begin{array}{c}107 \\
5 \\
\end{array}$ & 495 & 59 & 1 \\
\hline Jul & 49 & 4863 & 0 & $\begin{array}{c}172 \\
0 \\
\end{array}$ & 2 & $\begin{array}{c}263 \\
6 \\
\end{array}$ & 128 & 33 & 304 & 146 & 294 & 160 & 24 & 2 \\
\hline $\mathrm{Ags}$ & 65 & 1731 & 0 & 310 & 5 & 929 & 140 & 26 & 523 & 103 & 866 & 378 & 63 & 4 \\
\hline Sep & 81 & 3619 & 0 & 877 & 0 & $\begin{array}{c}139 \\
4 \\
\end{array}$ & 188 & 31 & 730 & 79 & $\begin{array}{c}105 \\
1 \\
\end{array}$ & 463 & 87 & 7 \\
\hline Okt & 71 & 3729 & 0 & 590 & 0 & $\begin{array}{c}109 \\
6 \\
\end{array}$ & 232 & 21 & 725 & 105 & 870 & 424 & 81 & 3 \\
\hline Total & 464 & $\begin{array}{c}1779 \\
6 \\
\end{array}$ & 8 & $\begin{array}{c}456 \\
2 \\
\end{array}$ & 8 & $\begin{array}{c}876 \\
7 \\
\end{array}$ & $\begin{array}{c}113 \\
4 \\
\end{array}$ & 160 & $\begin{array}{c}413 \\
3 \\
\end{array}$ & 700 & $\begin{array}{c}585 \\
1 \\
\end{array}$ & $\begin{array}{c}260 \\
1\end{array}$ & 401 & 23 \\
\hline $\begin{array}{c}\text { Rata- } \\
\text { Rata }\end{array}$ & & 38 & 0 & 10 & O & 19 & 2 & 0 & 9 & 2 & 13 & 6 & 1 & 0 \\
\hline
\end{tabular}

Sumber : PT. Trisakti Lautan Mas 2016 ( data diolah)

Tabel 3

Data pengguna jasa pada PT.Trisakti Lautan Mas cabang Bakauheni Lampung

Tahun 2016

\begin{tabular}{|c|c|c|c|c|c|c|c|c|c|c|c|c|c|c|}
\hline $\begin{array}{c}\text { Bula } \\
\mathbf{n}\end{array}$ & $\begin{array}{c}\text { Tri } \\
\text { p }\end{array}$ & $\begin{array}{l}\text { Pnp } \\
\text { Dws } \\
\text { dan } \\
\text { Ank }\end{array}$ & $\begin{array}{l}\text { Spd.Dy } \\
\text { g Gol I }\end{array}$ & $\begin{array}{c}\text { Spd. } \\
\text { Mtr } \\
\text { Gol } \\
\text { II }\end{array}$ & $\begin{array}{c}\text { Bem } \\
\text { o Gol } \\
\text { III }\end{array}$ & $\begin{array}{c}\text { KK } \\
\text { Gol } \\
\text { IV } \\
\text { A }\end{array}$ & $\begin{array}{c}\text { TM } \\
\text { Gol } \\
\text { IV } \\
\text { B }\end{array}$ & $\begin{array}{c}\text { BS } \\
\text { Go } \\
\text { I V } \\
\text { A }\end{array}$ & $\begin{array}{c}\text { TS } \\
\text { Gol } \\
\text { V B }\end{array}$ & $\begin{array}{c}\text { BB } \\
\text { Go } \\
\text { l } \\
\text { VI } \\
\text { A }\end{array}$ & $\begin{array}{c}\text { TB } \\
\text { Gol } \\
\text { VI } \\
\text { B }\end{array}$ & $\begin{array}{l}\text { TR } \\
\text { Gol } \\
\text { VII }\end{array}$ & $\begin{array}{c}\text { Gol. } \\
\text { VII } \\
\text { I }\end{array}$ & $\begin{array}{l}\text { Gol } \\
\text {. IX }\end{array}$ \\
\hline Apr & 81 & 2375 & 0 & 438 & 0 & 852 & 259 & 45 & 606 & 101 & 712 & 203 & 19 & 8 \\
\hline Mei & 77 & 3017 & 0 & 565 & 3 & $\begin{array}{c}109 \\
7 \\
\end{array}$ & 244 & 27 & 525 & 107 & 596 & 192 & 24 & 6 \\
\hline Jun & 69 & 2391 & 0 & 295 & 0 & 818 & 205 & 34 & 570 & 89 & 553 & 184 & 35 & 3 \\
\hline Jul & 58 & 3418 & 0 & 954 & 1 & $\begin{array}{c}147 \\
9 \\
\end{array}$ & 188 & 25 & 286 & 119 & 335 & 92 & 19 & 4 \\
\hline Ags & 69 & 2373 & 0 & 395 & 1 & 775 & 241 & 37 & 493 & 95 & 573 & 173 & 29 & 11 \\
\hline Sep & 45 & 1839 & 0 & 512 & 0 & 609 & 149 & 16 & 339 & 59 & 384 & 106 & 13 & 6 \\
\hline Okt & 26 & 623 & 0 & 148 & 0 & 296 & 80 & 12 & 199 & 37 & 195 & 64 & 8 & 3 \\
\hline Total & 425 & $\begin{array}{c}1603 \\
6 \\
\end{array}$ & 0 & $\begin{array}{c}330 \\
7 \\
\end{array}$ & 5 & $\begin{array}{c}592 \\
6 \\
\end{array}$ & $\begin{array}{c}136 \\
6 \\
\end{array}$ & 196 & $\begin{array}{c}301 \\
8 \\
\end{array}$ & 607 & $\begin{array}{c}334 \\
8 \\
\end{array}$ & $\begin{array}{c}101 \\
4 \\
\end{array}$ & 147 & 41 \\
\hline $\begin{array}{l}\text { Rata- } \\
\text { Rata } \\
\end{array}$ & & 38 & 0 & 8 & 0 & 14 & 3 & 0 & 7 & 1 & 8 & 0 & 0 & 0 \\
\hline
\end{tabular}

Sumber : PT. Trisakti Lautan Mas 2016 ( data diolah) 
Hal ini dengan kapasitas penumpang non kendaraan 200 orang, dan jumlah kendaraan \pm 100 unit sesuai jenis kendaraan, dari data diatas terdapat ketidak sesuaian jumlah penumpang rata-rata per trip dengan kapasitas yang disediakan, ketidak sesuaian jumlah penumpang pada hari biasa/ tidak libur (tidak tanggal merah) mengalami penurunan jumlah penumpang sangat sedikit, ini diakibatkan karena tingkat pengguna jasa oleh konsumen yang mengalami penurunan.

Berdasarkan latar belakang masalah di atas, penelitian berusaha mengetahui dan menganalisis terhadap variabel kualitas pelayanan, dan harga tambahan layanan yang mempengaruhi kepuasan konsumen, oleh karena itu penelitian ini mengambil judul "Pengaruh Kualitas Pelayanan dan Harga Tambahan Layanan Terhadap Kepuasan Konsumen Pengguna Jasa Kapal Penyebrangan di PT. Trisakti Lautan Mas Cabang Bakauheni, Lampung'”.

\section{Tujuan Penelitian}

1. Untuk menganalisis pengaruh Kualitas Pelayanan terhadap Kepuasan Konsumen pada PT Trisakti lautan Mas.

2. Untuk menganalisis pengaruhHarga Tambahan Layananterhadap Kepuasan Konsumen pada PT Trisakti Lautan Mas.

3. Untuk menganalisis pengaruh Kualitas Pelayanan dan Harga Tambahan Layanan secara Simultan terhadap Kepuasan Konsumen pada PT Trisakti Lautan Mas.

\section{LANDASAN TEORI DAN PENGEMBANGAN HIPOTESIS}

\section{Kualitas Pelayanan (Variabel $\mathbf{X}_{1}$ )}

Parasuraman, et al.(2009:148) Kualitas pelayanandapat didefinisikan sebagai seberapa jauh perbedaan antara kenyataan dan harapan pelanggan atas layanan yang mereka terima atau peroleh.

Tjiptono (2009:24)menyatakan bahwa terdapat 4 karakteristik pokok pada jasa yang membedakannya dengan barang. Keempat karakteristik tersebut meliputi:

a. Tidak tampak (intangibility) Jasa bersifat intangibility, artinya tidak dapat dilihat, dirasa, diraba atau didengar sebelum dibeli. Konsep intangibility ini sendiri meliputi dua pengertian. Kedua pengertian tersebut adalah :

1. Sesuatu yang tidak dapat disentuh dan tidak dapat dirasa.

2. Sesuatu yang tidak mudah didefinisikan, diformulasikan atau dipahami secara rohaniah.

b. Tidak terpisahkan.

c. Bervariasi.

d. Tidak tahan lama / tidak dapat disimpan. 
Prinsip-prinsip Kualitas Pelayanan

Menurut Wolkins, dkk dalam (Tjiptono, 2009:73)enam prinsip pokok dalam kualitas pelayanan meliputi:

1. Kepemimpinan

2. Pendidikan

3. Perencanaan

4. Review

5. Komunikasi

\section{Harga (Variabel $\mathbf{X}_{2}$ )}

Menurut William J Stanton dalam penelitian (Rezki 2014:5)harga adalah jumlah uang yang dibutuhkan untuk mendapatkan sejumlah kombinasi dari barang beserta pelayanannya.

Menurut William J Staton dalam penelitian (Rezki 2014:5) Indikator harga terdiri dari:

1. Keterjangkauan harga

2. Perbandingan dengan merk lain

3. Kesesuaian harga dengan kualitas

Penetapan Harga

Ada beberapa faktor yang mempengaruhi dalam penetapan harga, yakni :

1. Faktor-faktor internal, yang terdiri dari: tujuan pemasaran perusahaan, pertimbangan organisasi, sasaran pemasaran, biaya dan strategi bauran pemasaran.

2. Faktor-faktor eksternal, yang terdiri dari : situasi dan permintaan pasar, persaingan, harapan perantara, dan faktor-faktor lingkungan seperti kondisi sosial ekonomi, kebijakan dan perarturan pemerintah, budaya dan politik.

Tujuan penetapan harga jasa perlu dijabarkan ke dalam program penetapan harga jasa dengan mempertimbangkan faktor-faktor berikut :

1. Elastisitas harga permintaan Efektivitas program penetapan harga tergantung pada dampak perubahan harga terhadap permintaan, karena itu perubahan unit penjualan sebagai akibat perubahan harga perlu diketahui. Perubahan harga memiliki dampak ganda terhadap penerimaan penjualan perusahaan, yakni perubahan unit penjualan dan perubahan penerimaan per unit. 
2. Faktor persaingan Reaksi pesaing terhadap perubahan harga merupakan salah satu faktor penting yang perlu dipertimbangkan setiap perusahaan. Perubahan harga disamakan oleh semua pesaing, maka sebenarnya tidak akan ada perubahan pangsa pasar. Dalam hal ini, pengurangan harga tidak akan berdampak pada permintaan selektif.

3. Faktor biaya Struktur biaya perusahaan (biaya tetap dan biaya variabel) merupakan faktor pokok yang menentukan batas bawah harga. Artinya, tingkat harga minimal harus bisa menutup biaya (setidaknya biaya variabel).

4. Faktor lini produk Perusahaan bisa menambah lini produknya dalam rangka memperluas served market dengan cara perluasan lini dalam bentuk perluasan vertikal (vertical extension) dan perluasan horizontal. Dalam perluasan vertikal, berbagai penawaran berbeda memberikan manfaat serupa, namun dengan harga dan tingkat kualitas yang berbeda,dalam perluasan horizontalsetiap penawaran memiliki diferensiasi non harga tersendiri, seperti manfaat, situasi pemakaian, atau preferensi khusus.

5. Faktor pertimbangan lain dalam penetapan harga Faktor-faktor lain yang juga harus dipertimbangkan dalam rangka merancang program penetapan harga antara lain :

a. Lingkungan politik dan hukum, misalnya regulasi, perpajakan, perlindungan konsumen.

b. Lingkungan internasional, di antaranya lingkungan politik, ekonomi, sosial budaya, sumber daya alam dan teknologi dalam konteks global.

c. Unsur harga dalam program pemasaran lain, misalnya program promosi penjualan (seperti kupon, cents-off deals, promotion allowances, dan rabat) dan program penjualan dan distribusi (seperti diskon kuantitas, diskon kas, fasilitas kredit atau bantuan pembiayaan, kontrak jangka panjang, dan negotiated pricing).

\section{Kepuasan Pelanggan (Variabel Y)}

Menurut Tjiptono (2009:134)ada 2 model kepuasan konsumenyaitu:

a. Model kognitif

Penilaian pelanggan berdasarkan pada perbedaan antara suatu kumpulan dari kombinasi atribut yang dipandang ideal untuk individu dan persepsinya tentang kombinasi dari atribut yang sebenarnya,dengan kata lain penilaian berdasarkan perbedaan yang ideal dengan yang aktual,apabila yang ideal sama dengan persepsinya maka pelanggan akan puas, sebaliknya apabila perbedaan antara 
yang ideal dan yang aktual semakin besar makakonsumen semakin tidak puas. Berdasarkan model ini maka kepuasan pelanggan dapat dicapai dengan 2 cara yang utama, yaitu:

1. Mengubah penawaran perusahaan sehingga sesuai dengan yang ideal.

2. Meyakinkan pelanggan bahwa yang ideal tidak sesuai dengan kenyataanyang sebenarnya.

b. Model afektif

Model Afektif mengatakan bahwa penilaian pelanggan individual terhadap suatu produk tidak semata-mata berdasarkan perhitungan regional saja tetapi juga berdasarkan pada tingkat aspirasi, perilaku belajar (learning behavior), emosiperasaan spesifik (kepuasan, keengganan), suasana hati (mood) dan lainlain.

Indikator Kepuasan Konsumen

Hawkins dan Lonney dikutip dalam Tjiptono (2009:101) indikator kepuasan terdiri dari:

a. Kesesuaian harapan

Merupakan tingkat kesesuaian antara kinerja produk yang diharapkan oleh pelanggan dengan yang dirasakan oleh pelanggan, meliputi :

1. Produk yang diperoleh sesuai atau melebihi dengan yang diharapkan.

2. Pelayanan oleh karyawan yang diperoleh sesuai atau melebihi dengan yang diharapkan.

3. Fasilitas penunjang yang didapat sesuai atau melebihi dengan yang diharapkan.

b. Minat berkunjung kembali

Merupakan kesedian pelanggan untuk berkunjung kembali atau melakukan pembelian ulang terhadap produk terkait, meliputi :

1. Berminat untuk berkunjung kembali karena pelayanan yang diberikan oleh karyawan memuaskan.

2. Berminat untuk berkunjung kembali karena nilai dan manfaat yang diperoleh setelah mengkonsumsi produk.

3. Berminat untuk berkunjung kembali karena fasilitas penunjang yang disediakan memadai.

c. Kesediaan merekomendasikan

Kesediaan pelanggan untuk merekomendasikan produk yang telah dirasakannya kepada teman atau keluarga, meliputi :

1. Menyarankan teman atau kerabat untuk membeli produk yang ditawarkan karena pelayanan yang memuaskan.

2. Menyarankan teman atau kerabat untuk membeli produk yang ditawarkan karena fasilitas penunjang yang disediakan memadai. 
3. Menyarankan teman atau kerabat untuk membeli produk yang ditawarkan karena nilai atau manfaat yang didapat setelah mengkonsumsi sebuah produk jasa.

Atribut-atribut Pembentuk Kepuasan Konsumen Menurut Tjiptono (2009:101) ditengah beragamnya cara mengukur kepuasan pelanggan, terdapat kesamaan paling tidak dalam enam konsep inti mengenai objek pengukuran sebagai berikut:

1. Kepuasan Pelanggan Keseluruhan (Overall Customer Satisfaction).

2. Dimensi Kepuasan Pelanggan.

3. Konfirmasi Harapan (Confirmation of Expectation) .

4. Minat Pembelian Ulang (Repurchase Intent) .

5. Kesediaan untuk Merekomendasi (Willingness to Recommend) .

6. Ketidakpuasan Pelanggan (Customer Dissatisfaction) .

Gambar 1 Kerangka Pemikiran

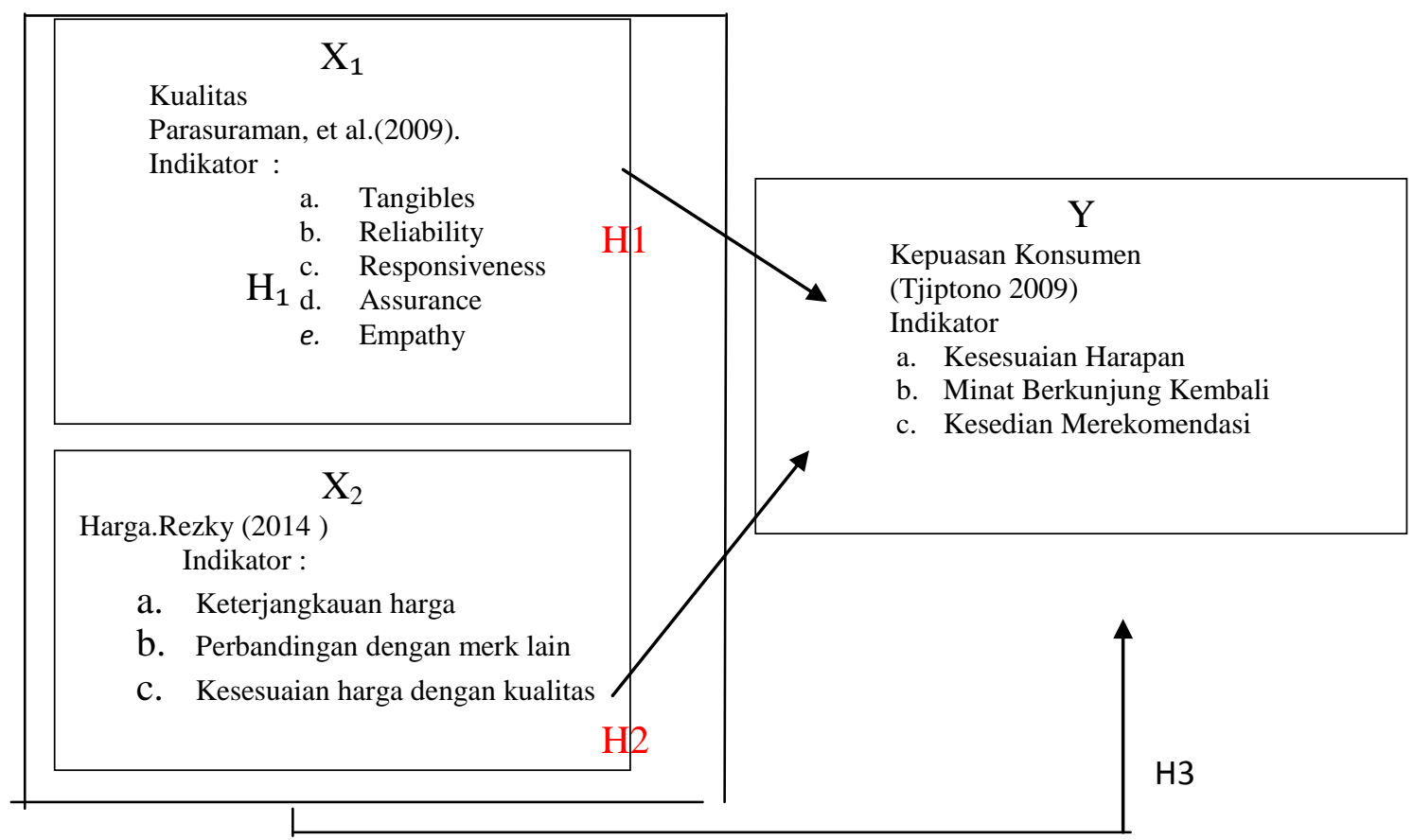

\section{METODE PENELITIAN}

\section{Hipotesis}

Berdasarkan latar belakang, landasan teori, dan kerangka berpikir, maka formulasi hipotesis yang dirumuskan untuk diuji kebenarannya dalam penelitan yang dilaksanakan di PT. Trisakti Lautan Mas.

Hipotesis penelitian ini secara statistic hipotesis tersebut dapat dirumuskan sebagai berikut : 
1. Diduga ada pengaruh kualitas pelayanan terhadap kepuasan konsumen pada PT. Trisakti Lautan Mas.

2. Diduga ada pengaruh harga tambahan layanan terhadap kepuasan konsumen pada PT. Trisakti Lautan Mas.

3. Diduga ada pengaruh kualitas pelayanan dan harga tambahan layanan secara simultan terhadap kepuasan konsumen pada PT. Trisakti Lautan Mas.

Karakteristik Responden

Tabel 4Identitas Responden berdasarkan Jenis Kelamin

\begin{tabular}{|l|c|c|}
\hline \multirow{2}{*}{ Jenis Kelamin } & \multicolumn{2}{|c|}{ Jumlah } \\
\cline { 2 - 3 } & & \multicolumn{2}{|c|}{} \\
\hline Laki-Laki & Frekuensi & Presentase (\%) \\
\hline Perempuan & 49 & $61,25 \%$ \\
\hline Tanpa Keterangan & 25 & $31,25 \%$ \\
\hline Total & 6 & $7,50 \%$ \\
\hline
\end{tabular}

Sumber : Hasil Pengolahan Data

Tabel 5Identitas Responden Berdasarkan Pekerjaan

\begin{tabular}{|l|c|c|}
\hline \multirow{2}{*}{ Pekerjaan } & \multicolumn{2}{|c|}{ Jumlah } \\
\cline { 2 - 3 } & Frekuensi & Presentase (\%) \\
\hline Karyawan BUMN & - & $0 \%$ \\
\hline Petani & 6 & $7,50 \%$ \\
\hline Wiraswasta & 11 & $13,75 \%$ \\
\hline PNS/TNI/Polisi & 3 & $3,75 \%$ \\
\hline Pegawai/ Karyawan Swasta & 17 & $21,25 \%$ \\
\hline Lain-Lain ( Supir ) & 23 & $28,75 \%$ \\
\hline Tanpa Keterangan & 20 & $25 \%$ \\
\hline Total & 80 & $100 \%$ \\
\hline
\end{tabular}

Sumber: Hasil Pengolahan Data

Tabel 6Identitas Responden BerdasarkanMenggunakan Transportasi Laut

\begin{tabular}{|c|c|c|}
\hline \multirow{2}{*}{ Menggunakan transportasi laut } & \multicolumn{2}{|c|}{ Jumlah } \\
\cline { 2 - 3 } & & Prekuensi \\
\hline Sering & 40 & $50 \%$ \\
\hline Tidak Sering & 32 & $40 \%$ \\
\hline Pertama Kali & 4 & $5 \%$ \\
\hline Tanpa keterangan & 4 & $5 \%$ \\
\hline
\end{tabular}


Total

80

$100 \%$

Sumber: Hasil Pengolahan Data

Tabel 7Identitas Responden Berdasarkan Alamat

\begin{tabular}{|c|c|c|}
\hline \multirow{2}{*}{ Alamat } & \multicolumn{2}{|c|}{ Jumlah } \\
\hline & Frekuensi & Presentase $(\%)$ \\
\hline Kota/Kab.Serang & 2 & $2,50 \%$ \\
\hline Provinsi Banten & 9 & $11,25 \%$ \\
\hline Provinsi Lampung & 20 & $25 \%$ \\
\hline Luar Provinsi Banten/Lampung & 38 & $47,50 \%$ \\
\hline Tanpa Keterangan & 11 & $13,75 \%$ \\
\hline Total & 80 & $100 \%$ \\
\hline
\end{tabular}

Sumber: Hasil Pengolahan Data

Penelitian ini bertujuan untuk menguji Pengaruh Kemampuan pembelajaran organisasi terhadap kualitas pelayanan $\left(\mathrm{X}_{1}\right)$, $\operatorname{Harga}\left(\mathrm{X}_{2}\right)$, dan Kepuasan Konsumen (Y).

Tabel 8Operasional Variabel

\begin{tabular}{|c|c|c|c|c|}
\hline $\begin{array}{l}\mathrm{N} \\
\mathrm{O}\end{array}$ & Variabel & Definisi Variabel & Indikator & $\begin{array}{l}\text { No. } \\
\text { Item }\end{array}$ \\
\hline 1 & $\begin{array}{l}\text { Kualitas } \\
\text { Pelayanan } \\
\quad\left(\mathrm{X}_{1}\right) \\
\text { Parasurama } \\
\text { n, et al }\end{array}$ & $\begin{array}{l}\text { Kualitas } \\
\text { Pelayanandapat } \\
\text { didefinisikan sebagai seberapa } \\
\text { jauh perbedaan antara kenyataan } \\
\text { dan harapan pelanggan atas } \\
\text { layanan yang mereka terima atau } \\
\text { peroleh. }\end{array}$ & $\begin{array}{l}\text { Tangibles } \\
\text { Reliability } \\
\text { Responsiveness } \\
\text { Assurance } \\
\text { Empathy }\end{array}$ & $\begin{array}{c}1-5 \\
6-9 \\
10-12 \\
13 \\
14-15\end{array}$ \\
\hline 2 & $\begin{array}{l}\text { Harga } \\
\left(X_{2}\right) \\
\text { Rizky }\end{array}$ & $\begin{array}{l}\text { Harga adalah jumlah uang yang } \\
\text { dibutuhkan untuk mendapatkan } \\
\text { sejumlah kombinasi dari barang } \\
\text { beserta pelayanannya }\end{array}$ & $\begin{array}{l}\text { Keterjangkaua } \\
\mathrm{n} \text { harga. } \\
\text { Perbandingan } \\
\text { dengan merk } \\
\text { lain } \\
\text { Kesesuaian } \\
\text { dengan kualitas }\end{array}$ & $\begin{array}{c}1-6 \\
7 \\
8-15\end{array}$ \\
\hline 3 & $\begin{array}{l}\text { Kepuasan } \\
\text { Pelanggan } \\
\text { ( Y ) } \\
\text { Tjiptono }\end{array}$ & $\begin{array}{llr}\text { Kepuasan } & \text { pelanggan } & \text { adalah } \\
\text { situasi } & \text { kognitif } & \text { pembeli } \\
\text { berkenaan dengan kesepadanan } \\
\text { atau ketidaksepadanan antara } \\
\text { hasil yang didapatkan } \\
\text { dibandingkan } & \text { dengan } \\
\text { pengorbanan yang dilakukan }\end{array}$ & $\begin{array}{l}\text { Kesesuaian } \\
\text { Harapan } \\
\text { Minat } \\
\text { Berkunjung } \\
\text { Kesediaan } \\
\text { Merekomendas } \\
\text { i }\end{array}$ & $\begin{array}{c}1-12 \\
13-14 \\
15\end{array}$ \\
\hline
\end{tabular}




\section{HASIL ANALISIS DAN PEMBAHASAN}

\section{Variabel dan Pengukuran Variabel}

Variabel yang terkait dalam penelitian ini adalah :

1. Variabel-variabel bebas / independent variabel $\left(\mathrm{X}_{1}\right.$ dan $\left.\mathrm{X}_{2}\right)$ Variabel bebas dalam penelitian ini adalah Kualitas Pelayanan $=X_{1}$ dan Harga $=X_{2}$

2. Variabel terikat / dependent variabel (Y)

Variabel terikat dalam penelitian ini adalah Kepuasan Konsumen (Y)

\section{Pengukuran Variabel}

Untuk memperoleh data yang diperlukan pengukuran yang dilakukan penulis menggunakan teknik pengumpulan data sebagai berikut :

a. Observasi (pengamatan).

b. Kuisioner, Pemberian skor dilakukan atas jawaban responden kemudian diberi skor dengan menggunakan skala likert.

\section{Populasi dan Pengambilan Sample}

Populasi dalam penelitian ini adalah seluruh Penumpang atau pengguna jasa PT.Trisakti Lautan Mas yang beroperasi di pelayaran Selat Sunda. Jumlah populasi yang diambil pada saat observasi selama 7 hari rata-rata 1 trip (penyebrangan ) 100 penumpang.

Jumlah penumpang rata-rata PT. Trisakti Lautan Mas sebanyak 80 penumpang dengan sampel uji instrumen 30 sampel dan uji sesungguhnya 80sampel.

\section{Metode Analisis Data}

Pengujian instrument dilakukan dengan menggunakan:

\section{Tanggapan Responden $\mathrm{X}_{1}$ dan $\mathrm{X}_{2}$ terhadap $\mathrm{Y}$}

Untuk melakukan penilaian terhadap kualitas dari variabel bebas dilakukan penggolongan dengan pertimbangan total bobot, dalam penelitian ini penulis akan menentukan banyaknya kelas interval, dengan perhitungan sebagai berikut :

Berikut ini tabulasi hasil kuisioner dengan variabel kualitas pelayanan dengan menyebarkan sebanyak 80 responden

Tabel 9 Rekapitulasi Tanggapan Responden KP $\left(\mathrm{X}_{1}\right)$

\begin{tabular}{|c|c|c|c|c|c|c|c|}
\hline No Item & STS (1) & TS (2) & RR (3) & S (4) & SS (5) & Jumlah & Keterangan \\
\hline KP1 & 0 & 1 & 59 & 15 & 5 & 264 & Cukup Baik \\
\hline KP2 & 0 & 29 & 49 & 2 & 0 & 213 & Cukup Baik \\
\hline KP3 & 0 & 0 & 2 & 65 & 13 & 331 & Baik \\
\hline KP4 & 0 & 0 & 3 & 62 & 15 & 332 & Baik \\
\hline KP5 & 10 & 63 & 7 & 0 & 0 & 157 & Tidak Baik \\
\hline KP6 & 1 & 46 & 33 & 0 & 0 & 192 & Tidak Baik \\
\hline KP7 & 0 & 0 & 65 & 15 & 0 & 255 & Cukup Baik \\
\hline KP10 & 0 & 3 & 24 & 39 & 14 & 304 & Baik \\
\hline KP14 & 0 & 2 & 30 & 44 & 4 & 290 & Baik \\
\hline
\end{tabular}




\begin{tabular}{|c|c|c|c|c|c|c|c|} 
KP15 & 0 & 12 & 54 & 12 & 2 & 244 & Cukup Baik \\
\hline Jumlah & 11 & 156 & 326 & 254 & 53 & 2582 & \\
\hline \multicolumn{8}{|c|}{ Rata-Rata } \\
\hline
\end{tabular}

Berdasarkan jawaban dari responden diatas, maka untuk variabel Kualitas Pelayanan diperoleh hasil rata-rata 258,2 dari semua nilai kuesioner termasuk dalam kategori "Cukup Baik", dan terdapat pula rata-rata disetiap indikator dari dimensi.

Tabel 10 Rekapitulasi Tanggapan Responden HTL $\left(\mathrm{X}_{2}\right)$

\begin{tabular}{|c|c|c|c|c|c|c|c|}
\hline No Item & STS (1) & TS (2) & RR (3) & S (4) & SS (5) & Jumlah & Keterangan \\
\hline HTL1 & 7 & 49 & 24 & 0 & 0 & 177 & Tidak Baik \\
\hline HTL2 & 16 & 48 & 16 & 0 & 0 & 160 & Tidak Baik \\
\hline HTL3 & 2 & 51 & 25 & 2 & 0 & 187 & Tidak Baik \\
\hline HTL4 & 1 & 50 & 28 & 1 & 0 & 189 & Tidak Baik \\
\hline HTL5 & 3 & 53 & 24 & 0 & 0 & 181 & Tidak Baik \\
\hline HTL9 & 0 & 51 & 29 & 0 & 0 & 189 & Tidak Baik \\
\hline HTL10 & 0 & 57 & 22 & 1 & 0 & 184 & Tidak Baik \\
\hline HTL11 & 9 & 52 & 18 & 1 & 0 & 171 & Tidak Baik \\
\hline HTL13 & 0 & 41 & 29 & 10 & 0 & 209 & Baik \\
\hline HTL14 & 4 & 49 & 27 & 0 & 0 & 183 & Tidak Baik \\
\hline Jumlah & 61 & 501 & 242 & 15 & 0 & 1830 & \\
\hline \multicolumn{7}{|c|}{ Rata-Rata } \\
\hline
\end{tabular}

Berdasarkan jawaban dari responden diatas, maka untuk Harga Tambahan Layanan di peroleh hasil rata-rata 183 dari semua nilai kuesioner termasuk dalam kategori "Tidak Baik".

Tabel 11 Rekapitulasi Tanggapan Responden KK (Y)

\begin{tabular}{|c|c|c|c|c|c|c|c|}
\hline No Item & STS (1) & TS (2) & RR (3) & S (4) & SS (5) & Jumlah & Keterangan \\
\hline KK1 & 7 & 36 & 35 & 2 & 0 & 193 & Tidak Baik \\
\hline KK2 & 2 & 36 & 42 & 0 & 0 & 200 & Tidak Baik \\
\hline KK3 & 0 & 47 & 33 & 0 & 0 & 193 & Tidak Baik \\
\hline KK5 & 12 & 48 & 20 & 0 & 0 & 169 & Tidak Baik \\
\hline KK6 & 0 & 18 & 53 & 9 & 0 & 231 & Cukup Baik \\
\hline KK7 & 3 & 55 & 22 & 0 & 0 & 179 & Tidak Baik \\
\hline KK10 & 2 & 48 & 29 & 1 & 0 & 189 & Tidak Baik \\
\hline KK11 & 4 & 60 & 16 & 0 & 0 & 172 & Tidak Baik \\
\hline KK13 & 1 & 41 & 38 & 0 & 0 & 197 & Tidak Baik \\
\hline Jumlah & 31 & 389 & 288 & 12 & 0 & 1723 & \\
\hline \multicolumn{7}{|c|}{ Rata-Rata } \\
\hline
\end{tabular}

Berdasarkan jawaban dari responden diatas, maka untuk variabel Kepuasan Konsumen diperoleh hasil rata-rata 191,4 dari semua nilai kuesioner termasuk dalam kategori "Tidak Baik".

\section{Uji Instrumen}




\section{Uji Validitas}

Dalam menguji dari data hasil kuisioner dari 80 responden dengan 15 pernyataan variabel Kualitas Pelayanan $\left(\mathrm{X}_{1}\right), 15$ pernyataan untuk variabel Harga $\left(\mathrm{X}_{2}\right)$, dan 15 pernyataan untuk variabel Kepuasan Konsumen (Y).Adapun hasil uji validitas, sebagai berikut :

Tabel 12 Uji Validitas Kualitas Pelayanan $\left(\mathrm{X}_{1}\right)$

\begin{tabular}{|l|c|c|c|}
\hline Item & \multicolumn{1}{|l|}{ hitung } & rabel & Keterangan \\
\hline KP.1 & 0,479 & 0,349 & Valid \\
\hline KP.2 & 0,368 & 0,349 & Valid \\
\hline KP.3 & 0,425 & 0,349 & Valid \\
\hline KP.4 & 0,412 & 0,349 & Valid \\
\hline KP.5 & 0,499 & 0,349 & Valid \\
\hline KP.6 & 0,480 & 0,349 & Valid \\
\hline KP.7 & 0,541 & 0,349 & Valid \\
\hline KP.8 & 0,319 & 0,349 & Tidak Valid \\
\hline KP.9 & 0,333 & 0,349 & Valak Valid \\
\hline KP.10 & 0,548 & 0,349 & Tidak Valid \\
\hline KP.11 & 0,317 & 0,349 & Tidak Valid \\
\hline KP.12 & 0,296 & 0,349 & Tidak Valid \\
\hline KP.13 & 0,247 & 0,349 & Valid \\
\hline KP.14 & 0,435 & 0,349 & Valid \\
\hline KP.15 & 0,494 & 0,349 & \\
\hline
\end{tabular}

Sumber : Hasil Pengolahan Data SPSS V.20

Tabel 13 Uji Validitas Harga Tambahan Layanan $\left(\mathrm{X}_{2}\right)$

\begin{tabular}{|l|c|c|c|}
\hline Item & r hitung & r table & Keterangan \\
\hline HTL.1 & 0,474 & 0,349 & Valid \\
\hline HTL.2 & 0,421 & 0,349 & Valid \\
\hline HTL.3 & 0,361 & 0,349 & Valid \\
\hline HTL.4 & 0,432 & 0,349 & Valid \\
\hline HTL.5 & 0,507 & 0,349 & Tidak Valid \\
\hline HTL.6 & 0,295 & 0,349 & Tidak Valid \\
\hline HTL.7 & 0,318 & 0,349 & Tidak Valid \\
\hline HTL.8 & 0,324 & 0,349 & Valid \\
\hline HTL.9 & 0,507 & 0,349 & Valid \\
\hline HTL.10 & 0,425 & 0,349 & Tidak Valid \\
\hline HTL.11 & 0,406 & 0,349 & Valid \\
\hline HTL.12 & 0,319 & 0,349 & Valid \\
\hline HTL.13 & 0,367 & 0,349 & Tidak Valid \\
\hline HTL.14 & 0,481 & 0,349 & 0,349 \\
\hline HTL.15 & 0,341 & & \\
\hline
\end{tabular}

Sumber : Hasil Pengolahan Data SPSS V.20

Tabel 14 Uji Validitas Kepuasan Konsumen (Y) 


\begin{tabular}{|c|c|c|c|}
\hline Item & r hitung & r tabel & Keterangan \\
\hline KK.1 & 0,406 & 0,349 & Valid \\
\hline KK.2 & 0,414 & 0,349 & Valid \\
\hline KK.3 & 0,464 & 0,349 & Valid \\
\hline KK.4 & 0,257 & 0,349 & Tidak Valid \\
\hline KK.5 & 0,435 & 0,349 & Valid \\
\hline KK.6 & 0,454 & 0,349 & Valid \\
\hline KK.7 & 0,356 & 0,349 & Valid \\
\hline KK.8 & 0,316 & 0,349 & Tidak Valid \\
\hline KK.9 & 0,277 & 0,349 & Tidak Valid \\
\hline KK.10 & 0,615 & 0,349 & Valid \\
\hline KK.11 & 0,499 & 0,349 & Valid \\
\hline KK.12 & 0,291 & 0,349 & Tidak Valid \\
\hline KK.13 & 0,528 & 0,349 & Valid \\
\hline KK.14 & 0,232 & 0,349 & Tidak Valid \\
\hline KK.15 & 0,344 & 0,349 & Tidak Valid \\
\hline
\end{tabular}

Sumber : Hasil Pengolahan Data SPSS V.20

\section{Uji Reliabilitas}

Reliabilitas adalah pengujian ketepatan atau keakuratan yang ditunjukan oleh pengukuran yang digunakan untuk mengetahui konsistensi alat ukur.

Tabel 15 Perbandingan Nilai Alpha dengan $r$ tabel

\begin{tabular}{|c|c|c|c|}
\hline Variabel & Nilai Alpha & $\begin{array}{c}\text { Rule of Themb } \\
\text { Normally }\end{array}$ & Kesimpulan \\
\hline $\mathrm{X}_{1}$ & 0,610 & 0,60 & Reliabel \\
\hline $\mathrm{X}_{2}$ & 0,602 & 0,60 & Reliabel \\
\hline $\mathrm{Y}$ & 0,601 & 0,60 & Reliabel \\
\hline
\end{tabular}

Sumber : Hasil Pengolahan Data SPSS V.20

Berdasarkan uji reliabilitas nilai alpha yang diperoleh dari variabel adalah $>\mathrm{r}$ dan itu artinya bahwa seluruh pernyataan yang terdapat pada kuisioner dapat dinyatakan reliabel.

\section{Uji Asumsi Klasik}

Uji Normalitas

Untuk mengetahui apakah model regresi pada penelitian ini berdistribusi normal atau tidak, dibawah ini adalah uji normalitas menggunakan tabel Kolmogorov-Smirnov dan grafik P-P Plot 
Tabel 16 Hasil Kolmogorov-Smirnov

One-Sample Kolmogorov-Smirnov Test

\begin{tabular}{|ll|r|r|r|}
\hline & & KP_X1 & HTL_X2 & KK_Y \\
\hline $\mathrm{N}$ & & 80 & 80 & 80 \\
Normal Parameters & Mean & 32.16 & 22.68 & 21.51 \\
& Std. Deviation & 2.617 & 2.823 & 2.470 \\
& Absolute & .129 & .129 & .126 \\
Most Extreme Differences & Positive & .125 & .129 & .095 \\
& Negative & -.129 & -.084 & -.126 \\
Kolmogorov-Smirnov Z & & 1.156 & 1.155 & 1.131 \\
Asymp. Sig. (2-tailed) & & .138 & .139 & .155 \\
\hline
\end{tabular}

a. Test distribution is Normal.

b. Calculated from data.

Berdasarkan hasil perhitungan pada tabel diperoleh hasil Sig.(2-tailed) pada variabel Kualitas Pelayanan $\left(\mathrm{X}_{1}\right)$ lebih besar dari $0,05(0,138>0,05)$, maka data variabel Kualitas Pelayanan berdistribusi normal. Untuk hasil Sig(2-tailed) pada variabel Harga $\left(\mathrm{X}_{2}\right)$ lebih besar dari $0,05(0,139>0,05)$, maka data variabel Harga Tambahan Layanan berdistribusi normal. Dan untuk hasil Sig.(2-tailed) pada variabel Kepuasan Konsumen(Y) lebih besar dari 0,05 (0,155>0,05), maka data variabel Kepuasan Konsumen berdistribusi normal.

Gambar 2 Grafik Normalitas

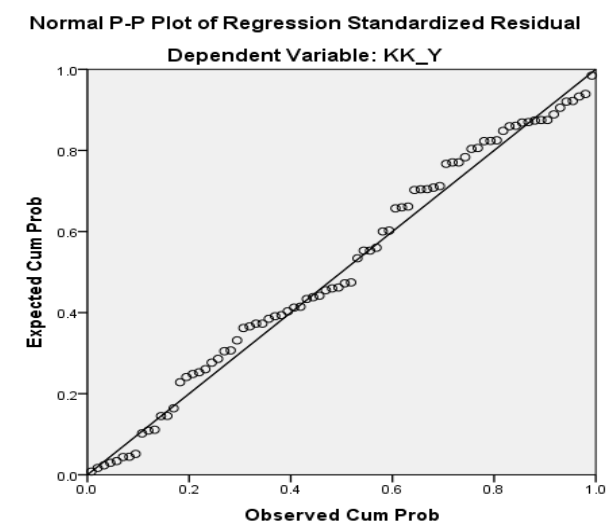

Sumber : Hasil Pengolahan Data SPSS V.20

Selain uji One-Sample Kolmogrov-Smirnovjuga menguji P-P Plot Of Regression maka grafikdisimpulkan model regresi memenuhi asumsi normalitas, hal ini terlihat bahwa kurva pada grafik terlihat mengikuti dan mendekati garis diagnoal.

Uji Multikolinieritas

Uji multikolinieritas bertujuan untuk mengetahui apakah ditemukan adanya korelasi antar variabel bebas (independent) dalam model 
regresi. Untuk mendeteksi ada tidaknya multikolinieritas pada model regresi menggunakan cara dengan melihat nilai tolerancedan VIF (Variance Inflation Factor). Nilai yang direkomendasikan untuk menunjukan tidak adanya multikolinieritas adalah nilai tolerance harus $>0,05$ dan nilai VIF < 5.

Tabel 17 Hasil Uji Multikolinieritas

\begin{tabular}{|c|c|c|c|c|c|c|c|}
\hline & & & Coefficients $^{\mathrm{a}}$ & & & & \\
\hline \multirow[t]{2}{*}{ Model } & \multicolumn{2}{|c|}{$\begin{array}{c}\text { Unstandardized } \\
\text { Coefficients }\end{array}$} & \multirow{2}{*}{$\begin{array}{c}\begin{array}{c}\text { Standardized } \\
\text { Coefficients }\end{array} \\
\text { Beta }\end{array}$} & \multirow[t]{2}{*}{$\mathrm{t}$} & \multirow[t]{2}{*}{ Sig. } & \multicolumn{2}{|c|}{ Collinearity Statistics } \\
\hline & B & Std. Error & & & & Tolerance & VIF \\
\hline (Constant) & 13.122 & 3.562 & & 3.684 & .000 & & \\
\hline KP_X1 & .159 & .109 & .168 & 1.459 & .149 & .909 & 1.100 \\
\hline HTL_X2 & .145 & .101 & .166 & 1.441 & .154 & .909 & 1.100 \\
\hline
\end{tabular}

a. Dependent Variable: KK_Y

Dari hasil uji multikolinieritas diperoleh nilai tolerance variabel Kualitas Pelayanan dan Harga Tambahan Layanan sama-sama sebesar 0,909 > 0,05 dan nilai VIF untuk kedua variabel juga sama-sama sebesar 1,100 $<5$, maka disimpulkan tidak terdapat problem multikolinieritas antar variabel independen dalam model regresi.

\section{Uji Heteroskedastisitas}

Untuk mendeteksi gejala heteroskedastisitas ada atau tidaknya pola yang terjadi pada nilai residu pada model dibawah ini, metode yang dapat digunakan adalah metode statistik glejser, gejala heteroskidastisitas akan ditunjukan oleh koefisien regresi dari masing-masing variabel independent terhadap nilai absolut residunya (e), jika nilai probabilitasnya lebih besar dari nilai alphanya $(0,05)$, maka dapat dipastikan model tidak mengandung unsur heteroskedastisitas.

Tabel 18 Hasil Uji Heteroskedastisitas

Coefficients $^{\mathrm{a}}$

\begin{tabular}{|c|c|c|c|c|c|c|}
\hline \multirow{2}{*}{\multicolumn{2}{|c|}{ Model }} & \multicolumn{2}{|c|}{ Unstandardized Coefficients } & \multirow{2}{*}{$\begin{array}{c}\begin{array}{c}\text { Standardized } \\
\text { Coefficients }\end{array} \\
\text { Beta }\end{array}$} & \multirow[t]{2}{*}{$\mathrm{t}$} & \multirow[t]{2}{*}{ Sig. } \\
\hline & & B & Std. Error & & & \\
\hline \multirow{3}{*}{1} & (Constant) & 13.122 & 3.562 & & 3.684 & .000 \\
\hline & KP_X1 & .159 & .109 & .168 & 1.459 & .149 \\
\hline & HTL_X2 & .145 & .101 & .166 & 1.441 & .154 \\
\hline
\end{tabular}

a. Dependent Variable: KK_Y

Uji Glejser diatas maka diperoleh nilai signifikansi untuk semua variabel lebih besar dari 0,05 . Oleh karena itu dapat disimpulkan bahwa pada model regresi tidak terjadi gejala heteroskedastisitas. 


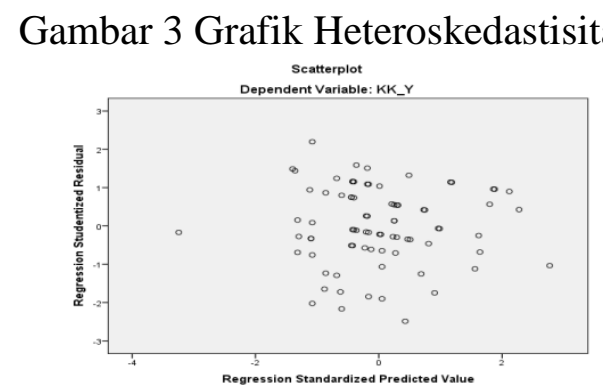

Berdasarkan pada gambar3, maka uji heterokdastisitas dihasilkan adalah tidak ada pola yang jelas serta titik-titik menyebar diatas dan di bawah angka 0 pada sumbu Y maka tidak terjadi heterosdastistas.

\section{Analisis Regresi Linier Berganda}

Analisis regresi adalah analisis yang dilakukan untuk mengukur besarnya pengaruh variabel bebas terhadap variabel terikat. Perhitungan analisis regresi menggunakan program SPSS V.20 dan adapun model kelayakan regresi linear didasarkan pada hal-hal sebagai berikut :

1. Predictor yang digunakan sebagai variabel bebas harus layak, kelayakan ini diketahui jika angka standar Error Of Estimate < Standar Deviation.

2. Data harus berdistribusi normal.

Tabel 19 Hasil Uji Regresi Linier Berganda Coefficients $^{\mathrm{a}}$

\begin{tabular}{|c|c|c|c|c|c|c|}
\hline \multirow{2}{*}{\multicolumn{2}{|c|}{ Model }} & \multicolumn{2}{|c|}{ Unstandardized Coefficients } & \multirow{2}{*}{$\begin{array}{c}\begin{array}{c}\text { Standardized } \\
\text { Coefficients }\end{array} \\
\text { Beta }\end{array}$} & \multirow[t]{2}{*}{$\mathrm{t}$} & \multirow[t]{2}{*}{ Sig. } \\
\hline & & $\mathrm{B}$ & Std. Error & & & \\
\hline \multirow{3}{*}{1} & (Constant) & 13.122 & 3.562 & & 3.684 & .000 \\
\hline & KP_X1 & .159 & .109 & .168 & 1.459 & .149 \\
\hline & HTL X2 & .145 & .101 & .166 & 1.441 & .154 \\
\hline
\end{tabular}

a. Dependent Variable: KK_Y

Berdasarkan hasil tabel 4.50 diatas, model persamaan regresi diperoleh adalah sebagai berikut :

$\mathrm{Y}=\mathrm{a}+\mathrm{b}_{1} \mathrm{X}_{1}+\mathrm{b}_{1} \mathrm{X}_{2}+\mathrm{e}$

$\mathrm{Y}=13,122+0,159 \mathrm{X}_{1}+0,145 \mathrm{X}_{2}+\mathrm{e}$

\section{Analisis Koefisien Determinasi $\left(\mathbf{R}^{2}\right)$}

Koefisien determinasi menunjukan berapa persen dan variasi (naik turunnya) variabel dependent dapat diterangkan atau dijelaskan oleh variasi variabel independent.

Tabel 20 Hasil Koefisien Determinasi $\left(\mathrm{R}^{2}\right)$

\section{Model Summary ${ }^{b}$}

\begin{tabular}{|c|c|c|c|c|}
\hline Model & $\mathrm{R}$ & R Square & Adjusted R Square & Std. Error of the Estimate \\
\hline 1 & $.269^{\mathrm{a}}$ & .073 & .048 & 2.409 \\
\hline
\end{tabular}

a. Predictors: (Constant), HTL_X2, KP_X1

b. Dependent Variable: KK_Y

Sumber : Hasil Pengolahan Data SPSS V.20 
Dari perhitungan diatas diperoleh nilai koefisien determinasi berganda $\left(\mathrm{R}^{2}\right)$ adjusted sebesar 0,048. Hal ini dapat diartikan bahwa variabel Kualitas Pelayanan $\left(\mathrm{X}_{1}\right)$ dan Harga $\left(\mathrm{X}_{2}\right)$ mempengaruhi 4,8\% terhadap Kepuasan Konsumen (Y). 95,2\% dipengaruhi faktor lain yang tidak diteliti oleh penulis.

\section{Uji Hipotesis}

Tabel 21 Hasil Uji t Hipotesis

Coefficients $^{\mathrm{a}}$

\begin{tabular}{|c|c|c|c|c|c|c|}
\hline \multirow{2}{*}{\multicolumn{2}{|c|}{ Model }} & \multicolumn{2}{|c|}{ Unstandardized Coefficients } & \multirow{2}{*}{$\begin{array}{c}\text { Standardized } \\
\text { Coefficients }\end{array}$} & \multirow[t]{2}{*}{$\mathrm{T}$} & \multirow[t]{2}{*}{ Sig. } \\
\hline & & $\mathrm{B}$ & Std. Error & & & \\
\hline \multirow{3}{*}{1} & (Constant) & 13.122 & 3.562 & & 3.684 & .000 \\
\hline & KP_X1 & .159 & .109 & .168 & 1.459 & .149 \\
\hline & HTL_X2 & .145 & .101 & .166 & 1.441 & .154 \\
\hline
\end{tabular}

a. Dependent Variable: KK_Y

Tabel 22 Hasil Uji F

ANOVA $^{\mathrm{a}}$

\begin{tabular}{|rl|r|r|r|r|r|}
\hline Model & & Sum of Squares & df & Mean Square & F & \multicolumn{1}{c|}{ Sig. } \\
\hline \multirow{2}{*}{1} & Regression & 34.973 & 2 & 17.487 & 3.012 & $.055^{\mathrm{b}}$ \\
& Residual & 447.014 & 77 & 5.805 & & \\
& Total & 481.988 & 79 & & & \\
\hline
\end{tabular}

a. Dependent Variable: KK_Y

b. Predictors: (Constant), HTL_X2, KP_X1

\section{Kriteria Pengambilan Keputusan}

Berdasarkan tabel hasil perhitungan Statistik uji $\mathrm{F}$ di atas, menunjukkan nilai Fhitung < F-tabel yaitu 3,012<3,12 maka dapat disimpulkan bahwa Ho diterima dan $\mathrm{H}_{\mathrm{a}}$ ditolak, Artinya Kualitas Pelayanan $\left(\mathrm{X}_{1}\right)$ dan Harga $\left(\mathrm{X}_{2}\right)$ secara bersamasama tidak terdapat pengaruh signifikan terhadap Kepuasan Konsumen (Y).

\section{PENUTUP}

Simpulan

Berdasarkan hasil analisis dan pembahasan, tentang Kualitas Pelayanan dan Harga Tambahan Layanan terhadap Kepuasan Konsumen pengguna jasa kapal penyebrangan di PT. Trisakti lautan Mas, Cab. Bakauheni Lampung , simpulan sebagai berikut

1. Tidak terdapat pengaruh positif dan tidak signifikan antara Kualitas Pelayanan terhadap Kepuasan Konsumenpada PT. Trisakti Lautan Mas, dikarenakan tidak adanya kebebasan konsumen untuk memilih kapal mana yang sesuai dengan kebutuhan konsumen.

2. Tidak terdapat pengaruh positif dan tidak signifikan antara Harga Tambahan Layanan terhadap Kepuasan Konsumen pada PT Trisakti Lautan Mas, 
dikarenakan tidak adanya kebebasan konsumen untuk memilih kapal mana yang sesuai dengan kebutuhan konsumen.

3. Tidak terdapat pengaruh antara Kualitas Pelayanan dan Harga Tambahan Layanan secara bersama-sama terhadap kepuasan konsumen pada PT. Trisakti Lautan Mas, artinya tidak terdapat pengaruh yang signifikan antara kualitas pelayanan dan harga tambahan layanan secara bersama-sama terhadap Kepuasan Konsumen pada PT Trisakti Lautan Mas, Cab. Bakauheni Lampung.

\section{Saran}

Berdasarkan dari kesimpulan di atas, maka penulis dapat memberikan saran-saran sebagai berikut :

1. Adapun yang perlu ditingkatkan menurut hasil dari rekapitulasi kualitas pelayanan dari indikator tangibles (KP.5) yaitu meningkatkan fasilitas keamanan ( petugas keamanan, kamera CCTV ).

2. Adapun yang perlu ditingkatkan menurut hasil dari rekapitulasi harga dari indikator keterjangkauan harga (HTL2) yaitu memberikan fasilitas gratis untuk ruang lesehan kepada penumpang.

3. Adapun yang perlu ditingkatkan menurut hasil dari rekapitulasi kepuasan konsumendari indikator kesesuaian harapan (KK.5) yaitu meningkatkan kebersihan dan jumlah toilet pada kapal.

\section{DAFTAR PUSTAKA}

Aditya, Reza Ryandi. (2011)."AnalisisPengaruhKesadaranMerek, Keragaman Menu,

PromosidanKualitasPelayananTerhadapKeputusanKonsumenUntukMemb eli Pizza Hut Dp Mall Semarang" Skripsi pada Universitas Negeri Semarang. Tidak Diterbitkan.

Ferdinand, Agusty (2012), Metode PenelitianManajemen. Semarang: Badan PenerbitUniversitas Diponegoro.

Haryanto, Ryan Nur. (2010)."AnalisisPengaruhHarga, Produk, KebersihandanKualitasPelayananTerhadapKepuasanKonsumenPadaRest oranMamamiaCabangMricanSemarang"Skripsi pada Universitas Negeri Semarang. Tidak Diterbitkan

Iswayanti, IkaPutri. (2010).”AnalisisPengaruhKualitasProduk, KualitasLayanan, HargadantempatTerhadapKepuasanKonsumenPadaRumahMakan Soto Angkringan Mas Boed di Semarang"Skripsi pada Universitas Negeri Semarang. Tidak Diterbitkan. 
Kotler, Philip dan Gary Armstrong. 2007. Manajemen Pemasaran. Jilid II. PTIndex, Jakarta.

Parasuraman, A., Zeithaml, V.A. dan Berry, L.L .(2008). Delivering Quality Service: Balancing Customer Perceptions and Exxpections, The free Press, New York: NY

Rezki, Rahmad. (2014). "Pengaruh Kualitas Produk, Harga, Lokasi dan Promosi Terhadap Keputusan Pembelian Ruko Pada CV.Sinar Jaya Global Steel Padang" Skripsi pada Universitas Taman Siswa Padang. Tidak Diterbitkan

Stanton, William J, 2000, Prinsip-prinsip Pemasaran, Jilid 1 Edisi ke 3, Alih Bahasa oleh Yohanes Lamarto, Jakarta: Erlangga.

Tjiptono, Fandy. (2008). Pemasaran Strategi.Yogyakarta : Andi.

Tjiptone, Fandy. (2009). Service, Quality dan Satisfacation Edisi ke 3 Yogyakarta: CV ANDI OFFSET.

Tjiptono, Fandy. (2014). Branding, \& Brand Longevity di Indonesia Yogyakarta: CV ANDI OFFSET.

Telan, Ariene Catherina. (2011)."AnalisisPengaruhFaktorTeknologi, KualitasLaayanan, danFokusPelangganTerhadapKepuasanKonsumenPadaPembeliProdukBa ndengElrina di Semarang"Skripsipada Universitas Negeri Semarang. Tidak Diterbitkan

Umar, Husein. (2013). Metode Penelitian untuk Skripsi dan Tesis Bisnis. Edisi Kedua, Jakarta : Rajawali Pers.

Wibowo, AriSusanto. (2013)."PengaruhHarga , Kualitas Pelayanan dan Nilai Pelanggan Terhadap Kepuasan Konsumen pada Rumah Makan di Kota Purwokerto" Skripsi pada Universitas Negeri Semarang. Tidak Diterbitkan

Yuwananto, Eko.(2011). “Pengaruh Kualitas Pelayanan dan Haraga Terhadap Kepuasan Pelanggan pada Usaha Badan Bangunan Sembilan Lima di Kecamatan Gunung Pati" Skripsipada Universitas Negeri Semarang. Tidak Diterbitkan

Jurnal

Arif, Sofyan. 2013. Kualitas Pelayanan Pengelolaan Atm Dan Kepuasan Nasabah.Jurnal EKOMEN, Vol 1, No.1 
Assegaff, Mohammad. 2009. “ Pengaruh Kualitas Pelayanan Terhadap KepuasanPelanggan” . Jurnal EKOBIS, Vol. 10, N0. 2 